\title{
KOMUNIKASI DOKTER YANG BERPUSAT PADA PASIEN DI MASA PANDEMI
}

\author{
Ilona Vicenovie Oisina Situmeang ${ }^{1}$, Ivonne Ruth Situmeang ${ }^{2}$ \\ ${ }^{1}$ Dosen Pascasarjana Ilmu Komunikasi Upi Yai Jakarta \\ ${ }^{2}$ Dosen Kedokteran Universitas Methodist Medan \\ Email: ilonoisina@yahoo.com
}

\begin{abstract}
ABSTRAK
Profesi dokter dalam melaksanakan tugas dan tanggungjawabnya tidak hanya mampu mendiagnosa pasien saja namun juga harus mampu berkomunikasi yang efektif dengan pasien sehingga pasien dapat dengan jujur menjelaskan gejala yang dirasakan oleh pasien. Dalam penelitian ini komunikasi dokter yang berpusat pada pasien terutama di masa pandemic seperti ini yang dikuatirkan adalah komunikasi yang terjalin adalah komunikasi yang kurang efektif dikarenakan rasa kuatir dan ketakutan. Komunikasi Dokter yang berpusat pada pasien meliputi enam aspek, yaitu: 1) Memperkuat hubungan (fostering the relationship), 2) Mengumpulkan informasi (gathering information), 3) Memberikan informasi, (providing information) 4) Mengambil keputusan (desicion making), 5) Merespon emosi (responding the emotions), 6) memampukan perilaku terkait pengobatan penyakit. (Enabling disease and treatment related behavior) yang merupakan pembahasan dalam penelitian ini.
\end{abstract}

Kata Kunci: Komunikasi, Komunikasi Dokter, Komunikasi Pasien, Masa Pandemi.

\section{PATIENT-CENTERED DOCTOR COMMUNICATION IN THE PANDEMIC TIME}

\begin{abstract}
communicate effectively with patients so that patients can honestly explain the symptoms felt by the patient. In this study, doctor-centered communication with patients, especially during a pandemic like this, the worry is that the communication that exists is ineffective because of worry and fear. Doctor's patient-centered communication includes six aspects, namely: 1) Strengthening the relationship (fostering the relationship), 2) Gathering information, 3) Providing information, (providing information) 4) Decision making, 5 ) Responding to emotions (responding to emotions), 6) enabling behavior related to illness. (Activating disease and treatment-related behavior) which is the discussion in this study..
\end{abstract}

Keywords: Communication, Doctor Communication, Patient Communication, Pandemic Period. 
Korespondensi: Dr. Ilona Vicenovie Oisina. Universitas Persada Indonesia, Jakarta. Jl. Diponegoro No. 74 Jakarta Pusat 10340. No. HP, WhatsApp: 081511617896 Email: ilonaoisina@yahoo.com

\section{PENDAHULUAN}

Isu kesehatan menjadi penting untuk dikaji terutama pada masa pandemik seperti ini. Pandemi Covid19 telah mengubah wajah dunia (Lestari dan Sularso, 2020) termasuk dibidang kesehatan. Komunikasi kesehatan antara dokter dan pasien pada masa pandemik seperti ini seringkali terjadi kurang efektif dikarenakan rasa takut yang berlebihan. Masa pandemik menimbulkan kekhawatiran bagi tenaga medis tertular virus COVID-19 yang disebabkan tidak terbukanya pasien dalam penggalian informasi pada panyakit yang diderita (Husain, 2020), namun dikarenakan suatu tanggungjwab yang harus dilaksanakan diharapkan dapat tetap tercipta komunikasi yang efektif antara dokter dan pasien. Dokter harus menggunakan APD (Alat Pelindung Diri) yang lemgkap untuk menjaga Kesehatan dirinya dari pasien.

Para tenaga medis yang bertugas harus merancang strategi dalam pembukaan diri pasien dengan memberikan presentasi diri sebagai tenaga medis baik, pasien membangun kepercayaannya dan nyaman dalam mengungkapkan dirinya pada proses anamnesis di masa pandemi sekarang (Husain, 2020). Namun seorang dokter harus tetap menjalankan tugas dan tnggung jawabnya dengan maksimal dengan cara berkomunikasi yang efektif.

Dalam konteks komunikasi, penting bagi seorang dokter untuk memiliki keterampilan komunikasi yang efektif terutama dimasa pandemik. Komunikasi merupakan bagian dari profesionalisme yang ditunjukkan dengan jelas berdasarkan knowledge atau pengetahuan, skill atau kemampuan serta attitude atau perilaku (Situmeang dan Tobing, 2020). Profesionalisme dokter adalah sebagai komitmen untuk ide professional dan karir (Kurtz S, Silverman J, Draper J, 2015). Pelayanan kesehatan, salah satu hal yang sangat penting adalah memiliki keterampilan komunikasi yang baik karena kemampuan komunikasi dokter kepada pasiennya memiliki hubungan signifikan dalam upaya kesembuhan pasien. Komunikasi dokter pasien adalah hubungan yang berlangsung antara dokter dengan pasiennya selama proses pemeriksaan yang terjadi di ruang praktik perorangan, poliklinik, rumah sakit, dan puskesmas dalam rangka membantu menyelesaikan masalah kesehatan pasien (Larasati, 2019).

Menurut Ong dkk, komunikasi antara dokter dan pasien merupakan jenis komunikasi yang berlangsung secara transaksional, face to face, dan berlangsung secara langsung. Jenis komunikasi ini melibatkan dua orang yang berbeda posisi, tidak sukarela, dan mengandung isi pesan yang penting sehingga membutuhkan kerjasama yang baik. Komunikasi antara dokter dan pasien adalah bentuk komunikasi kesehatan yang sifatnya interpersonal yang kompleks (Larasati, 2019). Komunikasi interpersonal yang efektif merupakan salah satu komponen penting dalam proses kesembuhan pasien yang harus dipertahankan oleh para tim medis. Dokter dan perawat perlu menjaga hubungan dan kerjasama yang baik dengan para pasien, karena dokter dan perawat merupakan orang terdekat yang dapat memahami masalah yang dialami oleh pasien secara komperehensif, sehingga pelayanan kesehatan dapat dilakukan secara menyeluruh (Roganda dkk, 2015). 
Komunikasi interpersonal antara tim medis dengan pasien dapat meningkatkan rasa percaya diri bagi pasien menuju kesembuhan, sehingga diharapkan tim medis dapat berkomunikasi secara kondusif dengan pasien sehingga membantu pasien dalam mengurangi beban penyakit yang dirasakan (Situmeang, 2018). Dalam melakukan komunikasi interpersonal dengan pasien dan keluarga pasien tenaga medis harus memiliki rasa empati yang tinggi akan keberadaan pasien.

Dalam memberikan pelayanan kesehatan yang berpusat pada pasien. Menurut WONCA of Europe (2011), pelayanan berpusat pasien dijabarkan dalam empat aspek, yaitu: doctor-patient relationship, centred on patient and context, promote patient empowerment, longitudinal continuity. Doctor-patient relationship atau hubungan dokter-pasien dibangun dalam komuniikasi dokter pasien yang efektif. Komunikasi dokter dan pasien berdasarkan konsep pelayanan berpusat pasien ini disebut dengan komunikasi dokter-pasien dengan berpusat pada pasien. Kemampuan komunikasi seorang dokter untuk memiliki kemampuan berkomunikasi yang baik dengan pasiennya memiliki tujuan yang berbeda-beda.

Pada masa pandemik seperti ini komunikasi yang terbentuk antara dokter dengan pasien diharapkan tetap berlangsung dengan efektif demi kesembuhan pasien. Dianne Berry mengungkapkan bahwa terdapat 3 (tiga) tujuan komunikasi dokter dan pasien yaitu: (1) Menciptakan hubungan interpersonal yang baik (creating a good interpersonal relationship), (2) Melakukan pertukaran informasi (exchange of information), dan (3) Pengambilan keputusan medis (medical decision making). Kemampuan komunikasi dokter dan pasien sebagai bentuk yang terjadi dalam berkomunikasi yaitu bagaimana dokter memiliki kemampuan untuk mengolah dan mentransformasikan informasi dari proses pertukaran informasi antara dokter dan pasien. Dalam proses pertukaran informasi yang dilakukan pada komunikasi dokter dan pasien merupakan salah satu faktor penentu keberhasilan proses komunikasi itu sendiri. (Larasati, 2019).

Dalam komunikasi kesehatan antara dokter-pasien, terdapat beberapa standar yang harus dipenuhi agar proses komunikasi dapat dikatakan efektif, yaitu: dokter selaku pemberi layanan kesehatan perlu menjawab semua pertanyaan yang diberikan pasien mengenai keluhan yang diderita pasien (Complete), ekspresi dan pesan yang diberikan oleh dokter harus relevan dengan keluhan pasien (Concise), kata-kata yang diberikan oleh dokter memiliki makna dan fakta yang terkait dengan pasien (Concrete), percakapan antara dokter-pasien haruslah singkat dan jelas agar pesan yang disampaikan dapat dipahami oleh pasien (Clear). Dalam komunikasi kesehatan yang efektif, dokter juga perlu menghindari penggunaan bahasa yang sulit dipahami oleh pasien seperti bahasa ilmiah kedokteran, bahasa yang merendahkan pasien, dll.

Dalam penelitian ini ingin meneliti tentang bagaimana komunikasi dokter yang berpusat pada pasien di masa pandemic? Sedangkan yang menjadi tujuan penelitian yaitu untuk mengetahui bagaimana komunikasi dokter yang berpusat pada pasien di masa pandemic untuk menghindari tertularnya Covid-19 dan juga membantu dan memotivasi pasien untuk kesembuhan. 
Teori dalam penelitian ini menggunakan teori Kredibilitas Sumber (source credibility theory) adalah teori yang dikemukakan oleh Hovland, Janis dan Kelley. Teori kredibilitas sumber (source of credibility theory) merupakan teori yang dikemukakan oleh Hovland, Janis dan Kelley dalam bukunya Communication and Persuasion. Adapun yang menjadi asumsi dari teori ini menyatakan bahwa orang akan lebih mungkin dipersuasi ketika komunikator atau orang yang meyampaikan pesan komunikasi menunjukkan dirinya sebagai orang yang kredibel atau dengan kata lain sumber komunikasi yang memiliki kredibilitas tinggi akan lebih efektif dalam mengubah opini seseorang dibandingkan dengan sumber komunikasi yang sumber kredibilitasnya rendah (Winoto, 2015). Dalam bentuk proses komunikasi seorang komunikator akan sukses apabila ia berhasil menunjukkan source of credibility, artinya menjadi sumber kepercayaan bagi komunikan kepada komunikator ditentukan oleh keahlian komunikator dalam bidang pekerjaannya serta dapat tidaknya dipercaya.

Teori ini menjelaskan bahwa seseorang akan lebih mudah dipersuasi jika sumber-sumber persuasinya cukup kredibel. Semakin kredibelnya sumber/komunikator maka akan semakin mudah mempengaruhi cara pandang audiens/ komunikan. Seringkali seseorang akan lebih percaya dan cenderung menerima dengan baik pesan-pesan yang disampaikan oleh orang yang memiliki kredibilitas di bidangnya. Seorang komunikator yang memiliki kredibilitas tentunya harus dapat mengemukakan berbagai pendapat terkait dengan upaya untuk mendukung proses mediasi yang sedang berlangsung. Suatu pesan persuasif menjadi semakin efektif apabila kita mengetahui bahwa penyampai pesan adalah orang yang ahli dibidangnya. Kredibilitas adalah bagian dari persepsi pihak yang menerima pesan (komunikan) tentang sifat-sifat penyampai pesan (komunikator). Dalam hal ini terdapat dua unsur yaitu, pertama kredibilitas merupakan persepsi publik, jadi tidak melekat dalam diri komunikator, kedua kredibilitas berhubungan dengan karakter atau kepribadian komunikator.

Dalam Teori Kredibilitas Sumber, kredibilitas komunikator dibentuk dari keterampilan seorang komunikator yang mempelajari semua informasi tentang objek yang dimaksud dan memiliki kepercayaan pada standar keaslian informasi yang dikirimkan. Dalam artian tersebut kredibilitas dalam Teori Kredibilitas Sumber terdapat dua unsur yakni, keterpercayaan dan keahlian yang dimiliki oleh penyampai pesan/ komunikator (Winoto, 2015).

Persuasi adalah bentuk penanaman pengaruh yang bisa berwujud apa pun, mulai dari keyakinan, sikap, maksud, dan motivasi. Persuasi adalah bagian tidak terpisahkan dari proses komunikasi individu, seorang pengirim pesan (sender) berusaha untuk memberikan dan memperbesar pengaruh pesan yang di sampaikan kepada penerima pesan (receiver). Persuasi adalah sebuah proses yang bertujuan untuk mengubah sikap atau perilaku individu baik secara personal maupun kelompok terhadap satu buah isu,tema, peristiwa atau objek yang lainnya baik bersifat abstrak seperti ide atau sesuatu yang actual seperti produk yang di gunakan. Usaha ini di lakukan baik dengan melalui jalur verbal atau nonverbal dengan cara mengonversi informasi,perasaan,atau alasan atau kombinasi semuanya ke dalam bentuk lain yang dapat di terima oleh si penerima pesan. 
Komunikasi antara dokter dan pasien adalah bentuk komunikasi kesehatan yang sifatnya interperonal yang komplek. Komunikasi kesehatan merupakan studi yang mempelajari bagaimana cara menggunakan strategi komunikasi untuk menyebarluaskan informasi kesehatan yang dapat mempengaruhi individu dan komunitas agar mereka dapat membuat keputusan yang tepat berkaitan dengan pengelolaan kesehatan, komunikasi kesehatan adalah merupakan studi yang menekankan peranan teori komunikasi yang dapat digunakan dalam penelitian dan praktek yang berkaitan dengan promosi kesehatan dan pemeliharaan kesehatan (Liliweri, dalam Candrasari dan Kurniasari, 2021).

Menurut Northouse dalam (Basuki, 2010), ada beberapa unsur yang mempengaruhi komunikasi kesehatan antara petugas kesehatan dengan pasien, yaitu: 1. Empathy, dokter berusaha untuk memahami cara pandang pasien,yang mana dokter berusaha merasakan apa yang sedang dialami oleh pasien. 2. Control, dokter mampu mengontrol jalannya komunikasi dengan pasien 3. Trust, dokter dapat membangun rasa saling percaya dengan pasien. 4. Self-Disclosure, dokter mengungkapkan dirinya terkait fakta diri kepada pasien. 5. Confirmation, dokter menanyakan kembali apakah pesan yang disampaikan sudah dimengerti oleh pasiennya.

Menurut National Cancer Institute, komunikasi berpusat pada pasien adalah komunikasi yang membangun hubungan antara dokter dan pasien berdasarkan kepercayaan, rasa saling menghormati dan komitmen antara dokter dan pasien dimana komunikasi ini harus berkontribusi dalam meningkatkan kesejahteraan pasien dan mengurangi penderitaan pasien karena penyakitnya setelah pasien selesai konsultasi dengan dokter. Menurut Guastello, Planetree dan Hale, komunikasi berpusat pada psien adalah proses pertukaran informasi dua arah yang kolaboratif antara dokter dan pasien, yang berbeda dari model patriarkal yang telah diabadikan selama beberapa generasi melalui praktik pelayanan kesehatan yang menciptakan kesan formal/tidak terjalin keakraban antara pasien dan dokter.

Berdasarkan hasil penelitian dan pendapat yang bervariasi tentang definisi komunikasi berpusat pasien, Ann King, MA and Ruth B. Hopp merumuskan aspek komunikasi berpusat pasien sebagai 6 konsensus tentang "Best practice" bagi komunikasi dokter pada konsultsai medis, yaitu: 1) Memperkuat hubungan (fostering the relationship), 2) Mengumpulkan informasi (gathering information), 3) Memberikan informasi, (providing information) 4) Mengambil keputusan (desicion making), 5) Merespon emosi (responding the emotions), 6) memampukan perilaku terkait pengobatan penyakit. (Enabling disease and treatment related behavior) (Caninsti, dkk, 2017)

\section{METODE PENELITIAN}

Paradigma yang akan digunakan dalam penelitian ini adalah paradigma konstruktivitis. Pendekatan penelitian dengan menggunakan kualitatif dan sifat penelitian menggunakan deskriptif. Dalam penelitian ini menggunakan Teknik pengumpulan data secara primer melalui wawancara mendalam dan observasi, sedangkan secara primer melalui studi Pustaka dan dokumentasi. Penelitian ini menggunakan tiga orang informan yang diwawancarai untuk menjawab dari pertanyaan penelitian yaitu tiga orang dokter informan 
yang pertama dokter spesialis THT berinisial JT, informan kedua dokter umum berinisial HDS dan informan yang ketiga dokter umum berinisial JP.

\section{HASIL DAN PEMBAHASAN}

Menciptakan hubungan interpersonal yang baik (creating a good interpersonal relationship) antara dokter dengan pasien merupakan prasyarat yang harus dijalankan oleh dokter saat sedang melakukan pemeriksaan tidak terkecuali dimasa pandemic seperti ini. Justru pada masa pandemic seperti ini dokter harus memberikan pelayanan yang prima untuk mendukung dan memotivasi pasien agar segera sembuh dari penyakit yang dideritanya. Hubungan dokter dan pasien yang baik dan komunikatif akan berdampak positif bagi kesembuhan pasien.

Aspek penting yang harus dimiliki oleh dokter yaitu aspek keterampilan komunikasi dalam menangani pasiennya. Apabila dokter memiliki keterampilan komunikasi yang baik dan efektif dalam memberikan pelayanan kesehatan, hal tersebut dapat membuat pasien mempunyai sugesti bahwa ia akan sembuh (Sari, 2013). Komunikasi dokter yang berpusat pada pasien adalah bentuk komunikasi kesehatan yang sifatnya interpersonal yang kompleks. Komunikasi dokter dengan pasien harus tercipta pertukaran informasi (exchange of information), dari sudut pandang dokter perlu untuk mendapatkan informasi yang lengkap dan jujur dari pasien untuk menyakini diagnosis yang tepat dan rencana perawatan.

Dari perspektif pasien perlu mengetahui dan memahami dan merasa dikenal dan dipahami oleh dokter. Dalam rangka untuk memenuhi kedua kebutuhan ini, kedua belah pihak harus melakukan komunikasi yang bersifat interaktif antara pemberian informasi dan bertukar informasi. Komunikasi yang bersifat interaktif, langsung dan dialogis merupakan peristiwa komunikasi antara dokter terhadap paseien dalam pelayanan Kesehatan. Komunikasi interpersonal dengan titik tolak saling memberikan pengertian antara dokter, paramedis dan pasien yang dirancang untuk tujuan pengobatan (Kurtz dkk, 2015)

Komunikasi dokter dan pasien dipengaruhi oleh beberapa aspek seperti pengetahuan, pengalaman, baik yang ada pada diri pasien maupun dalam diri dokter. Model berpusat pada pasien menekankan pentingnya memahami pengalaman pasien dari penyakit mereka, serta faktor-faktor sosial dan psikologis yang relevan. Berarti dokter menggunakan keterampilan mendengarkan aktif. Menurut Dokter JT salah satu dokter THT mengatakan bahwa:

"Pada saat melaksanakan profesinya seorang dokter terutama pada masa pandemik harus mampu melakukan komunikasi yang efektif, mendengarkan informasi yang disampaikan oleh pasien dan juga memiliki rasa empati terhadap penyakit yang dideritanya sehingga pasien dengan nyaman mengungkapkan gejala yang dirasakan, harus dapat menggali dan mendapatkan informasi yang jujur dari pasien sehingga dokter dapat menganalisis dan mendiagnosa penyakit yang diderita oleh pasien."

Kunci sukses hubungan dokter dan pasien adalah pada saat tercipta komunikasi yang efektif yang terjadi antara dokter dengan pasien. Seorang dokter harus mampu memberitahukan tentang penyebab penyakit, pilihan pengobatan dan strategi pencegahan secara professional kepada pasien, tetapi pasien tidak merasakan 
ketakutan melainkan memiliki motivasi yang tinggi untuk sembuh setelah mengetahui tentang penyakitnya. Profesionalisme seorang dokter berarti paham menempatkan profesi sebagai titik perhatian utama dalam kesembuhan pasien. Dalam melakukan komunikasi yang baik untuk diterapkan adalah komunikasi yang berpusat pada pasien, terdapat enam aspek, diantaranya adalah:

\section{Memperkuat hubungan (FosteringTthe Relationship)}

Aspek pertama yaitu membina hubungan antara dokter dan pasien, dimana dokter bertanggung jawab untuk membina hubungan dan membangun koneksi dengan pasien, tampak hangat, terbuka dan jujur, menghargai pendapat, privasi dan otonomi pasien, dan mengekspresikan kepedulian dan komitmen. Menurut JP salah seorang dokter umum mengatakan bahwa:

"Pada masa pandemik seperti ini biasanya komunikasi antara dokter dan pasien menjadi tidak efektif dikarenakan dokter dan pasien merasakan ketakutan saat berkomunikasi, namun sebagai profesi dokter yang berpusat pada pasien rasa ketakutan tersebut harus dihilangkan agar komunikasi yang terjalin akan tetap efektif, sehingga dokter dapat membina hubungan dan membangun koneksi dengan pasien hal ini akan berdampak rasa nyaman pasien pada saat menyampaikan gejala dan penyakitnya kepada dokter. Disaat tertentu dokter juga harus menjadi pendengar yang baik. Jika pasien sudah merasa nyaman akan menyampaikan dengan jujur dan dapat membantu dokter dalam mengambil keputusan yang tepat terhadap penyakit yang diderita" Pada aspek ini, dokter harus memiliki kemampuan untuk menyambut atau menyapa pasien dengan kehangatan sehingga pasien tidak merasakan ketidaknyaman dalam menyampaikan informasi, menjaga kontak mata dengan pasien dengan memperlihatkan rasa empati terhadap penyakit yang diderita oleh pasien, Menurut HDS salah satu dokter umum yang menjadi salah satu informan dalam penelitin ini menyatakan bahwa:

"Pada saat pertama kali memulai komunikasi dengan pasien biasanya dosen mempunyai berbagai macam strategi agar membuat pasien merasakan kenyamanan. Jika pasien sudah merasa nyaman pasti akan menceritakan secara jujur dengan gejala yang dirasakan oleh pasien. Namun jika diawal pasien merasakan tidak nyaman bisa saja pasien takut sehingga tidak ingin menyampaikan semua gejala dan keluhan yang dirasakan"

Pada saat tertentu dokter harus menjadi pendengar yang baik dokter tidak boleh memotong pembicaraan pasien namun membiarkan pasien menceritakan tentang gejala yang dideritanya. Pada saat melakukan komunikasi dengan pasien sebaiknya dokter menggunakan bahasa yang baik dan mudah dipahami pasien tidak menggunakan Bahasa kedokteran yang kemungkinan tidak dipahami oleh pasien, Serta harus mampu memotivasi pasien untuk dapat melalui penyakit ini dengan baik dan akan segera sembuh dari penyakit yang dideritanya, dengan cara menunjukkan ketertarikan dokter terhadap pasiennya. Memulai komunikasi seorang dokter kepada pasiennya harus dengan komunikasi yang baik sehingga menciptakan rasa nyaman bagi pasiennya.

\section{Mengumpulkan informasi (Gathering Information)}

Aspek kedua yaitu mengumpulkan informasi, dimana dokter mencoba untuk mendengarkan dan memahami penyakit yang diderita oleh pasien dengan menggali informasi selengkap mungkin sehingga 
mendapatkan deskripsi yang lengkap tentang gejala yang dirasakan oleh pasien. Menurut JP sebagai salah seorang dosen umum yang dijadikan informan dalam penelitian ini mengatakan bahwa:

"Hal yang tersulit bagi seorang dokter pada saat mengumpulkan informasi dari pasien, hal ini harus memiliki kemampuan khusus sehingga pasien dapat menjelaskan kronologis dari penyakit yang dideritanya tanpa ada hal yang ditutup-tutupi. Mengumpulkan informasi yang akurat membantu dokter dalam mengambil Tindakan selanjutnya. Seringkali pasien menyampaikan informasi yang tidak jujur dan tidak konsisten tentang gejala yang dialaminya sehingga menyulitkan kami sebagai dokter untuk mendiagnosa penyakit yang dialami oleh pasien."

Pada aspek ini dokter harus memiliki kemampuan untuk mengajukan pertanyaan kepada pasien terkait dengan gejala yang dialaminya namun tidak, mempersalahkan pasien atau menyalahkan pasien tentang penyakit yang dideritanya. Selain itu juga harus menjadi mendengarkan secara aktif sehingga tidak memunculkan kekhawatiran bagi pasiendan dapat menyimpulkan dari informasi yang disampaikan oleh pasien.

\section{Memberikan informasi, (Providing Information)}

Aspek yang ketiga yaitu menyediakan informasi, dimana dokter harus berusaha memahami kebutuhan informasi untuk pasien. Berbagi informasi dengan pasien tentang penyakit yang dideritanya namun juga tidak menyalahkan pasien. Memfasilitasi pemahaman pasien, dan menyediakan sumber daya informasi dan membantu pasien mengevaluasi juga menggunakannya. Menurut JT salah seorang dokter THT yang menjadi informan dalam penelitian ini mengatakan bahwa:

"Dalam memberikan informasi kepada pasien seorang dokter harus mampu menyampaikan dengan menggunakan Bahasa yang mudah untuk dimengerti oleh pasien dan tidak harus menakut-nakutin pasien dengan berbagai kemungkinan yang akan terjadi jika tidak melakukan apa yang disarankan oleh dokter hal ini akan menyebabkan rasa trauma pasien dan akan memperburuk Kesehatan pasien. Menyampaikan kebenaran kepada pasien merupakan keharusan bagi seorang dokter tanpa harus menakut-nakutin pasien."

Menurut Edmund Pellegrino, menyatakan kebenaran adalah tuntutan moral universal yang keberlakuannya melampaui pembatasan kultur tertentu. Setiap orang-termasuk dokter-wajib mengatakan yang benar karena kapabilitas manusia dalam melakukan pilihan-pilihan otonom tidak dapat berfungsi dengan baik jika kebenaran tidak dikatakan [ditahan], difalsifikasi, atau bahkan dimanipulasi (Kling, 2012). Menurut JP salah seorang dokter umum yang menjadi salah satu informan dalam penelitian ini mengatakan bahwa:

"Seorang dokter harus memiliki kemampuan untuk menjelaskan masalah kesehatan pasien dan pendekatan untuk diagnosis dan pengobatannya, memberikan penjelasan dan instruksi yang tidak rumit, menggunakan informasi utama dan harus menghindari penggunaan jargon dan kompleksitas yang akan membingungkan pasien. Selain itu juga diharapkan dokter juga harus mampu mendorong pasien untuk berani bertanya kepada dokter akan sesuatu hal yang tidak dipahaminya." Memberitahukan informasi secara keseluruhan tentang keadaan pasien adalah tuntutan prinsip beneficence dalam etika biomedis. Prinsip beneficence menegaskan bahwa seorang dokter harus menyampaikan informasi yang benar mengenai keadaan pasien dalam cara di mana menguntungkan (beneficence) dan tidak merugikan pasien (do no harm). Dalam hal ini tidak perlu menakut-nakutin pasien 
dan mengancam pasien jika tidak melakukan yang disarankan oleh dokter. Namun memberikan rasa nyaman sehingga dengan sendirinya pasien akan melakukan yang disarankan oleh dokter.

\section{Mengambil Keputusan (Desicion Making)}

Aspek keempat yaitu pengambilan keputusan, dimana dokter mempersiapkan pertimbangan pasien dan memungkinkan pengambilan keputusan yang tepat yang didapatkan dari informasi yang disampaikan oleh pasien sehingga informasi yang jujur dari pasien akan membantu dokter untuk mengambil keputusan yang tepat, serta mendorong pembuatan rencana kolaborasi yang baik antara dokter dan pasien. Sesuai dengan pendapat yang disampaikan oleh JP sebagai salah seorang dokter umum yang menjadi informan dalam penelitian ini mengatakan bahwa:

"Pengambilan keputusan yang tepat merupakan hal yang diharapkan oleh pasien, namun hal ini berkaitan erat dengan informasi yang disampaikan oleh pasien. Jika pasien menyampaikan gejala dan penyakit yang dideritanya secara jujur maka pengambilan keputusan yang dilakukan oleh dokter akan tepat pada sasaran penyakitnya namun sebaliknya jika ada yang ditutup-tutupi oleh pasien akan merugikan pasien itu sendiri karena pengambilan keputusan yang dilakukan oleh dokter bisa saja tidak tepat dikarenakan hal tersebut."

Pada aspek ini dokter harus memiliki kemampuan untuk mendorong pasien berpartisipasi dalam pengambilan keputusan yang telah disampaikan oleh dokter. Dalam menyampaikan informasi informasi, dalam konteks etika biomedis, pasien memang memiliki hak-hak seperti (1) Hak atas informasi; (2) Hak untuk menolak pengobatan; (3) Hak atas privasi; (4) Hak atas catatan medis rumah sakit; dan (5) Keikutsertaan secara sukarela dalam penelitian (Thomas A. Shannon, 1995). Namun dokter juga harus mampu mengajak dengan cara tidak memaksa agar pasien tertarik untuk mengikuti saran yang diberikan oleh dokter. Memotivasi pasien agar semangat untuk sembuh dengan mengikuti saran-saran yang diberikan oleh dokter.

\section{Merespon emosi (Responding the Emotions)}

Aspek kelima yaitu memungkinkan perilaku terkait penyakit dan pengobatan, dimana dokter bertanggung jawab untuk menilai minat dan kapasitas pasien dalam manajemen diri, memberikan saran (kebutuhan informasi, keterampilan koping, strategi untuk keberhasilan), membantu pasien untuk mengoptimalkan otonomi dan manajemen diri dari masalahnya agar pasien tidak menyalahkan dirinya sendiri atas penyakit yang dideritanya, melakukan advokasi, dan membantu pasien dengan sistem kesehatan. Seperti yang disampaikan oleh JT salah seorang dosen THT yang menjadi informan dalam penelitian ini mengatakan bahwa:

"Dalam menyampaikan informasi kepada pasien seorang dokter harus benar-benar memahami kondisi yang dialami oleh pasien jangan sampai menimbulkan masalah baru bagi pasien. Selain itu juga harus memberikan saran untuk pengobatannya. Sehingga ada solusi yang didapatkan oleh pasien."

Pada aspek ini dokter harus memiliki kemampuan untuk menilai kesiapan pasien untuk mengubah perilaku sehat, dan mendapatkan tujuan, ide, dan keputusan pasien. Namun dokter juga tidak berhak untuk 
menyalahkan pasien akan penyakit yang dideritanya. Dengan menyampaikan informasi kepada pasien harus memperhatikan psikis dari pasien sehingga membantu pasien dalam menjalankan pengobatan. Memotivasi pasien agar tidak ketakutan dengan penyakit yang dialaminya akan membantu pasien semangat untuk menjalankan pengobatan.

\section{Memampukan perilaku terkait pengobatan penyakit. (Enabling Disease and Treatment Related \\ Behavior)}

Aspek yang terkahir yaitu respon terhadap emosi pasien, dimana dokter bertanggung jawab untuk memfasilitasi ekspresi emosional pasien terhdap penyakitnya dan memiliki kemampuan untuk mengetahui dan mengeksplorasi emosi pasien, mengekspresikan empati, menyediakan bantuan yang berkaitan dengan emosi dan menilai distres psikologi pasien. Menurut pendapat JP sebagai seorang dokter umum yang menjadi salah seorang informan dalam penelitian ini mengatakan bahwa:

Dalam setiap keputusan yang diambil oleh dokter terkait dengan penyakit yang dialaminya biasanya untuk penyakit yang beresiko kecil dokter dengan mudah memotivasi pasien untuk melakukan pengobatan berbeda dengan penyakit yang dialami oleh pasien beresiko besar harus memiliki strategi yang tepat dalam memberikan saran kepada pasien dan juga keluarga pasien. Jika dalam menyampaikan saran pengobatan tidak tepat akan beresiko pasien tidak mau melaksanakan anjuran dari dokter.

Peran dan tanggung jawab dokter serta kebutuhan keterampilan yang harus dimiliki agar dapat mempersuaikan pasien dan juga memotivasi pasien agar tertarik untuk melakukan pengobatan dan menjelaskan kepada pasien bahwa penyakitnya dapat disembuhkan. Seorang dokter tidak hanya dituntut mampu untuk mendiagnosa penyakit yang dialami oleh pasien saja namun juga harus mampu memotivasi dan membaca psikis dari pasien sehingga tujuan pengobatan dapat dterlaksana sesuai dengan yang diharapkan.

Menciptakan hubungan interpersonal yang baik (antara dokter dan pasien yang baik dan komunikatif akan berdampak baik bagi penyembuhan pasien. Hal ini akan menciptakan kepuasan bagi pasien, Seorang yang berprofesi sebagai dokter diharapakn tidak hanya mampu mendiagnosa penyakit yang diderita oleh pasien namun juga harus mampu memciptakan hubungan interpersonal yang baik. Hubungan interpersonal yang baik antara dokter dengan pasien akan membuat pasien patuh terhadap sara pengobatan yang dianjurkan oleh dokter. Terkait dengan teori yang digunakan dalam penelitian ini adalah teori kredibilitas sumber dimana dalam teori ini mengatakan bahwa orang yang kredibel dibidangnya akan memiliki kemudahan berkomunikasi dengan orang lain. Jika dikaitkan dengan penelitian ini dokter dianggap kredibel dalam menyampaikan diagnosa penyakit yang diderita oleh pasien dan kredibel dalam menyarankan pengobatan bagi pasien, sehingga dengan komunikasi interpersonal yang terbina dengan baik akan membantu pasien menjadi percaya dengan informasi yang disampaikan dokter.

Dalam teori kredibitas sumber mengatakan bahwa memiliki Kemampuan dalam pembicaraan dengan audiens dalam hal ini pembicaraan dengan pasien. Biasanya informasi yang disampaikan oleh dokter akan didengarkan oleh pasien jika disampaikan dengan etika komunikasi yang baik. Pasien akan lebih mendengarkan saran dari dokter terkait dengan penyakit di deritanya dibandingkan dengan saran yang 
disampaikan oleh orang lain yang tidak memiliki kemampuan dibidang Kesehatan. Dalam teori kredibitas sumber mengatakan bahwa memiliki kepercayaan dari audiens dalam hal ini pasien. Pasien akan lebih mempercayai informasi yang disampaikan oleh dokter terkait dengan penyakit yang dialaminya. Kepercayaan pasien didasari dengan kredibilitas dokter dalam hal menyampaikan diagnose dan pengobatan.

Dalam teori kredibilitas sumber mengatakan bahwa ahli dalam mempengaruhi audiens dalam hal ini pasien. Dokter mempunyai pengaruh yang kuat untuk mempengaruhi pasien dalam pengobatan yang akan dilakukan. Kemampuan komunikasi dokter untuk mengolah dan mentransformasikan informasi dari proses pertukaran informasi antara dokter dan pasien merupakan salah satu faktor penentu keberhasilan proses komunikasi. Dalam membangun hubungan interpersonal yang baik dibutuhkan elemen penting yaitu keakraban, perhatian, kurangnya ketegangan, dan ekspresi nonverbal dari dokter dan pasien. Secara khusus, hubungan interpersonal dokter dan pasien yang baik akan meningkat ketika konteks kemampuan komunikasi dokter-pasien berlangsung dengan keramahan dokter, perilaku sopan santun, perilaku sosial dan perilaku empati selama melakukan konsultasi.

\section{SIMPULAN}

Dalam menjalankan profesi menjadi seorang dokter yang berpusat pada pasien diharapkan terciptanya komunikasi yang memunculkan dan memahami perspektif dari pihak pasien dengan melihat kekhawatiran, ide, harapan, kebutuhan, perasaan, dan fungsi yang ada pada diri pasien, memahami pasien dalam konteks psikisnya, harus mencapai pemahaman bersama tentang masalah yang dihadapi oleh pasien. Seorang dokter juga harus bisa memberikan pasien berbagai pilihan-pilihan yang berhubungan dengan masalah kesehatannya dan memberikan saran akan berbagai pilihan tersebut agar pasien dapat memilih dengan tepat dan pilihannya akan membuat pasien menjadi segera sembuh dari penyakit yang dideritanya. Dalam melakukan komunikasi yang berpusat pasien, dokter harus memiliki keterampilan dalam berkomunikasi dengan mengedepankan pemahaman akan perspektif pasien tentang penyakitnya dan harus mampu berempati terhadap penyakit pasien.

Diharapkan penelitian ini dapat memberikan saran bagi profesi dokter dalam menjalankan tugas dan tanggungjawabnya harus mampu menciptakan komunikasi yang interaktif dan nyaman antara dokter dengan pasien. Dokter harus mampu berempati terhadap penyakit yang sedang diderita oleh pasien dan sebaliknya diharapkan pasien juga harus jujur dalam menyampaikan gejala yang dialami oleh pasien sehingga dalam mengambil keputusan dokter tidak salah mediagnosa dan memberikan pengobatan kepada pasien.

\section{DAFTAR PUSTAKA}

Al Husain Andi Hasan. (2020). Komunikasi Kesehatan Dokter dan Pasien Berbasis Kearifan Lokal Sipakatau di Masa Pandemi. Jurnal Ilmu Komunikasi Volume 18, No. 2 August 2020, 126-141.

Basuki, E.S.M. (2010). Komunikasi Petugas Kesehatan dengan Klien dalam pelayanan kedokteran di Indonesia. Pidato pada upacara pengukuhan sebgai Guru Besar Tetap. Fakultas Kedokteran Universitas Indonesia 
Candrasari Satya dan Nani Kurniasari. (2021). Strategi Komunikasi Kampanye Kesehatan Marisza Cardoba Foundation (MCF) pada Program Nasional Senyum Indonesiaku. AGUNA: Jurnal Ilmu Komunikasi, Volume I, No. 2, Januari 2021, hlm. 1-15

Caninsti, Riselligia Rahmi Nur Hidayati, Alabanyo Brebahama, Endang Fourianalistyawati. (2015). Pemaknaan Pasien Terhadap Komunikasi Pelayanan Kesehatan Dokter Yang Bertugas Di Klinik Dan Puskesmas. Jurnal Psikogenesis, Volume 5, No.2, Desember 2017135

Joseph A. Devito. (2001). Komunikasi Antar Manusia. Tangerang Selatan: Kaharisma Publishing Group.

Kurtz S, Silverman J, Draper J. (2015). Teaching and learning communication skills in medicine. 2nd ed.Oxon: Radcliffe Publishing Ltd.

Larasati TA. (2019). Komunikasi Dokter-Pasien Berfokus Pasien pada Pelayanan Kesehatan Primer. Jurnal Kedokteran Universitas Lampung Volume 3 No 1 Maret 2019.

Lestari, P., \& Sularso. (2020). The COVID-19 Impact Crisis Communication Model Using Gending Jawa Local Wisdom. International Journal of Communication and Society, 2(1), 47-57. https://doi.org/10.31763/ijcs.v2i1.150

Roganda DP, dkk. (2015). Pola Komunikasi Interpersonal Teraupetik Dokter Terhadap Pasien Anak. Jakarta: Jurnal Bisnis dan Komunikasi Bisnisocio. ISSN 2356-4385 hal 183-193.

Sari, P.C.P. (2013). Faktor-Faktor Yang Memperngaruhi Keputusan Berobat Serta Dampaknya Terhadap Kepuasan Pasien. Fakultas Ekonomi dan Bisnis Universitas Diponegoro: Semarang.

Situmeang, Ilona V. Oisina (2018). Korelasi Komunikasi Interpersonal Efektif dan Kualitas Layanan Tim Media Terhadap Kepuasan Pasien. Fakultas Dakwah dan Komunikasi Universitas Islam Negeri (UIN) Sunan Ampel Surabaya, Surabaya Voluem 8 No 1 tahun 2018.

Situmeang, Ivonne Ruth dan Jerry Tobing. (2020). Komunikasi sebagai professionalisme Dokter Pada Era Digital Normal Baru. Book chapter Aspikom: Adaptasi Disiplin Ilmu Komunikasi Di Masa Normal Baru. 2020 hal 449-461.

WONCA. (2011). The European Definition Of General Practice / Family Medicine Wonca Europe 2011 Edition 1. 2011;1-33. Available from: http://www.wonca europe.org/.

Winoto. (2015). Penerapan Teori Kredibilitas Sumber (Source Of Credibility) dalam penelitian-penelitian layanan perpustakaan. EDULID Vol 5 No 2 Hal 1-14. 